University of Montana

ScholarWorks at University of Montana

\title{
Is Selectively Harvested Forest an Ecological Trap for Olive-Sided Flycatchers?
}

Bruce A. Robertson

Richard L. Hutto

University of Montana - Missoula, hutto@mso.umt.edu

Follow this and additional works at: https://scholarworks.umt.edu/biosci_pubs

Part of the Biology Commons

Let us know how access to this document benefits you.

\section{Recommended Citation}

Robertson, Bruce A. and Hutto, Richard L., "Is Selectively Harvested Forest an Ecological Trap for OliveSided Flycatchers?" (2007). Biological Sciences Faculty Publications. 268.

https://scholarworks.umt.edu/biosci_pubs/268

This Article is brought to you for free and open access by the Biological Sciences at ScholarWorks at University of Montana. It has been accepted for inclusion in Biological Sciences Faculty Publications by an authorized administrator of ScholarWorks at University of Montana. For more information, please contact scholarworks@mso.umt.edu. 


\title{
IS SELECTIVELY HARVESTED FOREST AN ECOLOGICAL TRAP FOR OLIVE-SIDED FLYCATCHERS?
}

\author{
Bruce A. Robertson ${ }^{1}$ AND Richard L. Hutto \\ Avian Science Center, Division of Biological Sciences, University of Montana, Missoula, MT 59812
}

\begin{abstract}
Disturbance-dependent species are assumed to benefit from forestry practices that mimic the appearance of postdisturbance landscapes. However, human activities that closely mimic the appearance but not the fundamental quality of natural habitats could attract animals to settle whether or not these habitats are suitable for their survival or reproduction. We examined habitat selection behavior and nest success of Olive-sided Flycatchers (Contopus cooperi) in a naturally occurring burned forest and an anthropogenically created habitat type - selectively harvested forest. Olive-sided Flycatcher density and nestling provisioning rates were greater in the selectively harvested landscape, whereas estimated nest success in selectively harvested forest was roughly half that found in naturally burned forest. Reduced nest success was probably a result of the relatively high abundance of nest predators found in the artificially disturbed forest. These results are consistent with the hypothesis that selectively harvested forest can act as an "ecological trap" by attracting Olive-sided Flycatchers to a relatively poor-quality habitat type. This highlights the importance of considering animal behavior in biodiversity conservation.
\end{abstract}

Key words: ecological trap, evolutionary trap, habitat preference, Olive-sided Flycatcher, selective harvest, timber management, wildfire.

\section{¿Es el Aprovechamiento Selectivo de los Bosques una Trampa Ecológica para Contopus cooperi?}

Resumen. Se supone que las especies que dependen de las perturbaciones se benefician de aquellas prácticas forestales que imitan la apariencia de los paisajes naturales después del las perturbaciones. Sin embargo, las actividades humanas que imitan de manera cercana la apariencia pero no la calidad fundamental de los hábitats naturales pueden atraer animales que se establecen independientemente de que dichos hábitats sean los más adecuados o no para su sobrevivencia o reproducción. Estudiamos el comportamiento de selección del hábitat y el éxito reproductivo de Contopus cooperi en un bosque quemado naturalmente y en un tipo de hábitat creado antropogénicamente-bosque con extracción selectiva. Las densidades y las tasas de alimentación de los polluelos de C. cooperi fueron mayores en las zonas con extracción selectiva, mientras que el éxito reproductivo estimado fue de casi la mitad en el paisaje con extracción selectiva en comparación con el bosque quemado naturalmente. El reducido éxito reproductivo fue probablemente el resultado de la mayor abundancia de depredadores de nidos en el bosque con perturbación artificial. Los resultados concuerdan con la hipótesis de que los bosques con extracción selectiva pueden actuar como "trampas ecológicas" atrayendo a C. cooperi a un tipo de hábitat de calidad relativamente pobre. Este hecho destaca la importancia de considerar el comportamiento animal en la conservación de la biodiversidad.

\section{INTRODUCTION}

When selecting a place to settle, animals must choose among potential habitats based on environmental and structural cues that, over evolutionary time, have become reliably correlated with components of habitat quality (Hutto 1985). However, if habitat selection behavior has been shaped by exposure to one set of conditions and animals are rapidly

Manuscript received 13 March 2006; accepted 30 October 2006.

${ }^{1}$ E-mail: bruce.robertson@mso.umt.edu confronted by novel or very different conditions, formerly reliable cues may trigger maladaptive settlement behavior (Tinbergen 1951, Levins 1968). This situation, in which a poor habitat becomes more attractive, thus luring individuals to settle, has been termed an "ecological trap" (Dwernychuk and Boag 1972, Schlaepfer et al. 2002). An ecological trap arises when sudden environmental change (e.g., pesticide use or human disturbance) acts to uncouple the cues that individuals use to assess habitat quality from the true quality of the environment (Schlaepfer et al. 2002, Robertson and Hutto 2006). An animal's prefer- 
ence remains unchanged, but the positive outcome normally associated with a given cue becomes a negative outcome (Misenhelter and Rotenberry 2000). Ecological traps are predicted to have significant, often dramatic, negative effects on the persistence of populations of wild animals (Delibes et al. 2001, Donovan and Thompson 2001, Kokko and Sutherland 2001).

Land-management practices that mimic the effects of natural disturbances (e.g., fire or windstorms) may result in areas that provide all the evolved stimuli that promote settling by an organism, but lack the ultimately important food resources or relief from predation normally associated with a naturally disturbed environment (Weldon and Haddad 2005). Historically, large-scale natural disturbances, especially fires, have played a major role in determining the structure of Rocky Mountain landscapes (Habeck and Mutch 1973, Frost 1998). Recently, however, timber harvesting has replaced wildfire as the dominant disturbance process shaping the landscape pattern of forest age classes (DeLong and Tanner 1996). Consequently, land managers are now encouraged to use green-tree retention techniques to mimic natural disturbance patterns (Hejl et al. 1995, Arno and Fiedler 2005).

Although forest management may show some similarities with natural disturbances (fire and insect outbreaks) to which organisms are adapted (Hutto 1995), there are important differences between these two types of disturbances. Specifically, timber harvesting modifies the structure and composition of forest mosaics in an unnatural fashion (Spies et al. 1994) by altering age-class distribution (Hejl et al. 1995, DeLong and Tanner 1996), disturbing soil, leaving coarse woody debris and live trees (Spies et al. 1994), and removing standing dead trees (Hutto 1995). Unlike typical, naturally occurring stand-replacement fire, where blackened trees remain after disturbance, postharvest forests are dominated by green trees. As such, harvested forests are "unnatural" in that their structure consists of combinations of elements (e.g., widely or evenly spaced live trees) that simply do not exist in natural successional seres. Burned-forest insect communities are also fundamentally different from those that occur in harvested forests (Short and Negrón 2003), as is the community of potential nest predators-particularly corvids and squirrels (Hutto and Young 1999, StuartSmith and Hayes 2003). Thus, harvested forests may act as ecological traps if they elicit settling responses by species that have evolved to respond to superficially similar, but fundamentally different, early successional forest types (Hutto and Young 1999), and if they cause poor reproductive success or adult survival due to altered food resources or unnaturally high predation rates (Stuart-Smith and Hayes 2003).

The Olive-sided Flycatcher (Contopus cooperi) is an ideal subject for a comparison of nest success between artificially and naturally created early postdisturbance habitats because it is not only relatively abundant in naturally disturbed, early postfire forests in the northern Rocky Mountains, but it is equally or more abundant in variously harvested forest types, specifically seed-tree, shelterwood, and clearcut forest types (Hutto and Young 1999). Thus, based on abundance data alone, this species appears to be a specialist of artificially or naturally created early postdisturbance environments. Within burned forest, this singlebrooded species (Altman and Sallabanks 2000) is most abundant in patches that have burned at high severity (Smucker et al. 2005). Thus, it could be considered a fairly narrow postfire specialist species, except for the fact that it also frequents artificially disturbed forests.

To demonstrate the existence of a 'severe' ecological trap (Robertson and Hutto 2006), three general criteria must be met: (1) individuals must exhibit a behavioral preference for one habitat over another; (2) a reasonable surrogate measure of individual fitness should differ among habitats; and (3) the fitness of individuals settling in the preferred habitat must be lower than the fitness attained in other available habitats. To date, empirical evidence for the existence of ecological traps is limited to only half a dozen examples, primarily because of the difficulty of demonstrating the existence and direction of habitat preferences (Robertson and Hutto 2006). Despite the difficulties associated with assessing habitat preference, we nonetheless tested several predictions that follow necessarily from the hypothesis that selectively harvested forests serve as ecological traps for the Olive-sided Flycatcher in the northern Rocky Mountains. 


\section{METHODS}

\section{STUDY SITE AND SPECIES}

We used an impact-reference design, with the reference site a previously unharvested forest that burned at high severity, and the impact site a green-tree forest affected by various selective harvesting techniques. We conducted our study in 2002 in two sites, one located in the 29000 ha Moose Fire that burned through Glacier National Park and Flathead National Forest in 2001, and the other on neighboring Plum Creek Timber Company land that was harvested in 1999-2001. Within the Flathead National Forest portion of the Moose Fire, we selected the 4000 ha Big Creek Basin as a study area. Burn severity was heterogeneous throughout this area and the minimum distance to the burn perimeter was $>1 \mathrm{~km}$. We located a study area similar in size and physiognomy on nearby Plum Creek Timber Company land. The forest structure consisted of patches of thinned forest interspersed with unharvested patches. Harvested and burned sites were of similar ageclass, forest type, elevation, and latitude. Both study areas were mid-elevation sites dominated by mixed-conifer forest stands of ponderosa pine, Douglas-fir (Pseudotsuga menziesii), western larch (Larix occidentalis), lodgepole pine (Pinus contorta), subalpine fir (Abies lasiocarpa), and Engelmann spruce (Picea engelmannii).

\section{TERRITORY AND NEST SITE SELECTION}

We characterized habitat features associated with nest territories within two weeks of fledging to enable comparisons between: (a) successful and failed nests, and (b) areas surrounding nest sites and randomly located, unoccupied sites. We measured floristic and structural habitat components thought to be important to Olive-sided Flycatchers at four spatial scales: nest, nest tree, and two plots centered on the nest tree-one an $11.5 \mathrm{~m}$ radius intensive plot, and the other a $36 \mathrm{~m}$ radius (oneacre) extensive plot. Information from additional $11.5 \mathrm{~m}$ and $36 \mathrm{~m}$ radius plots was also collected at randomly located unoccupied points. We estimated nest and tree heights by triangulation using a clinometer and measuring tape, and visually estimated the distance from each nest to the tree trunk. Nest concealment was visually estimated as the percentage of vegetation cover within $1 \mathrm{~m}$ above, and within a square meter centered on, the nest. We tallied the total number of trees and suitable nest trees in the understory (1.5-9 m tall) and at canopy height ( $>9 \mathrm{~m}$ tall) in both the $11.5 \mathrm{~m}$ and $36 \mathrm{~m}$ radius plots and recorded whether individual trees were alive (some green vegetation) or dead (all leaves brown). Suitable nest trees were defined as living or dead Engelmann spruce or subalpine fir that still retained some intact foliage (green or brown needles) within the top meter of trunk. We calculated the percentage of canopy cover surrounding the nest tree as the mean of five readings at $2 \mathrm{~m}$ intervals along transects in four cardinal directions made with an ocular estimation tube. At these same measurement intervals, we estimated the percentage of bare ground surrounding the nest tree as the percentage of ground occluded from above by live vegetation. We also assessed the heterogeneity of the forest canopy with the Shannon diversity index (Shannon and Weaver 1963) for trees $>9 \mathrm{~m}$ tall. We estimated ground slope within a $36 \mathrm{~m}$ radius surrounding nests and random points using a clinometer. Because vegetation characteristics did not differ significantly between the $11.5 \mathrm{~m}$ and $36 \mathrm{~m}$ radius plots within sites, we report only vegetation estimates collected at the $36 \mathrm{~m}$ radius scale. Fire severity surrounding nests was estimated within a $100 \mathrm{~m}$ radius using standardized severity criteria (U.S. Department of Interior 2001).

\section{HABITAT PREFERENCE}

We assumed that relative density was a reasonable surrogate measure of habitat preference, but also added information on flycatcher settlement patterns in the two habitat types as a second measure of preference. Specifically, we assumed that the males that arrived earliest on breeding grounds would select territories that they perceived to be the highest quality (Bensch and Hasselquist 1991, Aebischer et al. 1996, Fransson and Jakobsson 1998, Kokko 1999, Currie et al. 2000). Thus, we systematically surveyed each study area daily for territorial males, and the mean arrival time for a site was used as a measure of preference for that site relative to the other site.

We began surveying for territorial males in mid-May (before the arrival of any male). Singing males were detected from point count locations (burned: $n=41$, cut: $n=56$ ) that 
were evenly spaced along tertiary roads throughout the study areas. A conservative estimate of the detection distance for Olivesided Flycatchers is $250 \mathrm{~m}$ (Brandy 2001), so count locations were spaced at $500 \mathrm{~m}$ intervals. Each station was surveyed for $10 \mathrm{~min}$ daily prior to and throughout the arrival period (20 days after the arrival of the first male). Surveys began at a randomly selected station each day, but were executed in a consistent order until all points had been visited. We assumed that a male was defending a territory if he was detected for at least three consecutive days during the arrival period and if he was observed defending a territory at that location for at least five consecutive visits during nest searching activities. Arrival date was standardized as the number of days after arrival of the first male. Habitat-specific pairing success was estimated as the percentage of territorial males that were observed in association with a female on at least three separate occasions. Density estimates were calculated for each study area based on the number of territorial males.

\section{REPRODUCTIVE SUCCESS}

We attempted to locate and monitor all Olivesided Flycatcher nesting attempts using standard techniques (Ralph et al. 1993), and checked active nests a minimum of every four days. To avoid observer bias, two people searched for nests as a team, alternating between study areas on successive days. We searched for nests daily from the onset of nesting until late June, when birds no longer renested after failure (BAR, unpubl. data). Because Olive-sided Flycatchers may nest as high as $34 \mathrm{~m}$ (Altman and Sallabanks 2000), intensive nest monitoring would have required a telescoping nest pole, which may have disrupted nesting and attracted predators. Therefore, we monitored nests only to obtain estimates of nest success. A nest was considered successful if at least one young fledged. We confirmed fledging by sighting fledglings, listening for fledgling begging calls, or observing parents carrying food or scolding near the nest. A nest was considered unsuccessful if either no fledglings were located, adults did not scold when we were close to the nest site, the nest was empty before the expected fledging date, or a renesting attempt was located within the territory shortly after completion of a previous nesting attempt.

\section{FOOD AVAILABILITY AND NEST PREDATOR ABUNDANCE}

Based on the well-studied functional responses of animals to prey density (Holling 1965, 1966), the feeding rate of a predator should be proportional to food density until it can increase no further because of satiation or handling limitations. Nestling provisioning rates in aerial foragers are positively correlated with food density (Blancher and Robertson 1987) and the relationship seems consistent among studies (Hutto 1990). If food supply is a factor limiting Olive-sided Flycatcher reproductive success, provisioning of young should differ between the two habitat types. The number of feedings per chick per hour was estimated for each nest during the late nestling period ( $>10$ days after hatching), for two 30min periods during fair weather. The late nestling period was chosen to observe nestling feeding behavior because growth rates of nestlings are generally highest (Pereyra and Morton 2001), and therefore food demands are greatest, during this period (Walsberg 1978), which should thus best reflect food limitation (Hutto 1990). Because flycatchers exhibit a bimodal distribution of foraging activity throughout the day (Fitzpatrick 1981), two 30-min foraging bouts were observed for each nest on any given sample day: one during midmorning (10:0011:00) and one during midafternoon (15:0017:00). The observation period began immediately after the first feeding to reduce bias due to unequal disturbance caused by observers. Differences in average nestling provisioning rates between treatments were tested using an independent samples $t$-test.

To determine if differences in potential nest predator abundance differed between the burned and harvested habitat types, we compared the habitat-specific relative abundance of known nest predators of Olive-sided Flycatchers occurring in the study area-red squirrel (Tamiasciurus hudsonicus), Gray Jay (Perisoreus canadensis), and Common Raven (Corvus corax) - using point count data. Other potential nest predators included deer mice (Peromyscus maniculatus), and yellow pine chipmunks ( $\mathrm{Ta}$ mias amoenus), but, given the typical height of Olive-sided Flycatcher nests in this study (mean $=12.1 \pm 1.3 \mathrm{~m}$ ), we assumed that these generally terrestrial mammals were unlikely to be significant predators. Point counts were 
conducted concurrently with surveys for Olivesided Flycatchers during the arrival period using standard techniques (Ralph et al. 1993), and included all individuals detected within a $50 \mathrm{~m}$ radius. Locations were randomly selected points within the burned $(n=71)$ and selectively harvested $(n=80)$ study areas. We attempted to adjust for any source of detection bias due to habitat structure by using fixedradius data for our analyses, and we also explored the possibility that animals were detected more readily in open, burned habitat than in unburned habitat by examining detection profiles at burned and unburned points. Detection profiles were similar between burned and unburned points within $50 \mathrm{~m}$, suggesting that any differences in detection rates were unlikely to have been a result of differences in lateral detection probabilities. The relative abundance of predators in each site was computed as the average number of detections per point for that site.

\section{STATISTICAL ANALYSES}

We estimated daily nest survival (the probability that a nest survives a given day) and tested hypotheses about the causes of variation in daily nest survival using the generalized linear modeling approach of Shaffer (2004). We fit logistic-exposure models using PROC GENMOD (SAS Institute 1999), a binomial response distribution, and the link function defined by Shaffer (2004). We developed a set of a priori candidate models that reflected our assessment of likely causes of variation in nest survival. Candidate models were built using the following variables that we considered potentially important in explaining variation in nest success: (1) habitat, defined as either burned or harvested forest; (2) stage. Predators may use parental activity as a cue for locating nests. As a result, daily nest survival may decline from incubation to fledging as parents make more trips to the nest to provide food for their young (Skutch 1949, Martin et al. 2000). We modeled daily nest survival as a binomial response to the variable stage; (3) percent canopy cover. Canopy cover influences the abundance of known nest predator species and the likelihood of predation of artificial songbird nests in selectively harvested and burned forests in the northern Rocky Mountains (Stuart-Smith and Hayes 2003). Because canopy cover is also predicted to delineate treatments in this study, we considered a linear effect of canopy cover on nest success in the model set; (4) trunk distance. Olive-sided Flycatcher nests are typically quite conspicuous (Altman and Sallabanks 2000). However, nests located farther from the tree trunk may be more conspicuous than those located closer to the tree trunk. We examined whether the horizontal distance of a nest from the trunk of its supporting tree was linearly related to nest survival probability; (5) snag density. Tall, emergent snags are frequently used by Olive-sided Flycatchers as foraging perches (J. Wright, Alaska Department of Fish and Game, unpbl. data) and may be essential habitat components providing unobstructed air space that facilitates prey detection, so we included a linear density trend in daily nest survival in our model set; (6) slope. Because even relatively short perch trees and snags may provide high open-sky visibility for flycatchers if they are located on steep slopes we examined a linear effect of slope on nest survival.

Based on combinations of the above variables, we evaluated a candidate set of 14 a priori models that we believed could reasonably explain variation in nest survival. Given the relatively small sample size of nests available for analysis and the relatively large number of parameters evaluated, we did not include interaction terms in our models. Using the output from PROC GENMOD, we evaluated the degree of support for each model using goodness-of-fit tests (Hosmer and Lemeshow 1989) and second-order Akaike's information criterion $\left(\mathrm{AIC}_{c}\right.$; Akaike 1973), which includes a small-sample bias adjustment. A goodness-offit test of the global model was performed to determine whether this model provided an adequate fit to the data. The best model was selected by judging the degree of support as indicated by $\Delta \mathrm{AIC}_{c}$ and normalized Akaike weights. Models with $\Delta \mathrm{AIC}_{c} \leq 2$ were considered to have substantial support, whereas models with $\Delta \mathrm{AIC}_{c} \geq 4$ were considered to have little to no empirical support (Burnham and Anderson 2001).

We interpreted the explanatory strength of each variable by using odds ratios calculated from model-averaged coefficients and 95\% confidence intervals based on unconditional standard errors (Burnham and Anderson 1998). The use of model-averaged estimates incorpo- 
TABLE 1. Vegetation characteristics (mean $\pm \mathrm{SE}$ ) in the burned and selectively harvested forest study areas in northwestern Montana. Tree (understory height $=1.5-9.0 \mathrm{~m}$; canopy height $>9.0 \mathrm{~m}$ ) densities are recorded as trees per hectare. Suitable nest trees were defined as spruce or fir trees with some attached foliage within the top meter of the tree. Tree height diversity represents a measure of heterogeneity in the heights of canopy trees. The density of understory, living canopy, and suitable nest trees was greater in the selectively harvested landscape, whereas snag density was greater in the burned landscape.

\begin{tabular}{lcc}
\hline \hline \multicolumn{1}{c}{ Variable } & Burned $(n=18)$ & Selectively harvested $(n=18)$ \\
\hline Canopy tree density & $152.4 \pm 31.0$ & $118.0 \pm 22.6$ \\
Live canopy tree density* & $20.3 \pm 8.9$ & $112.7 \pm 21.6$ \\
Live understory tree density* & $6.2 \pm 5.1$ & $26.6 \pm 7.7$ \\
Spruce and fir tree density & $22.0 \pm 5.4$ & $29.1 \pm 9.6$ \\
Suitable nest tree density* & $2.1 \pm 1.1$ & $27.3 \pm 8.9$ \\
Spruce density* & $0.0 \pm 0.0$ & $22.8 \pm 5.3$ \\
Subalpine fir density* & $2.1 \pm 1.1$ & $13.1 \pm 6.6$ \\
Tree height diversity & $1.5 \pm 0.2$ & $1.8 \pm 0.2$ \\
Canopy cover $(\%)^{*}$ & $0.8 \pm 0.3$ & $8.2 \pm 2.5$ \\
Snag density* & $21.2 \pm 6.5$ & $0.6 \pm 0.2$ \\
Bare ground $(\%)^{*}$ & $56.1 \pm 8.2$ & $21.7 \pm 4.3$ \\
\hline
\end{tabular}

* Treatment means significantly different at $P \leq 0.02$. All other variables not significant (Mann-Whitney $U$ tests).

rates model selection uncertainty and provides a more robust indication of the effect of each variable on daily nest survival (Anderson et al. 2000). We selected odds ratios to evaluate the explanatory power of each variable because they are widely used in logistic regression and reflect effect size. We calculated the percentage change in the odds of nest survival for each oneunit change in an independent variable by subtracting 1 from the odds ratio and multiplying this value by 100 . We do not interpret odds ratios with confidence intervals that overlapped 1.

Estimates and their confidence limits were back-transformed from the logit scale for presentation (proportion $=e^{\text {estimate }} /\left[1+e^{\text {estimate }}\right]$ ). Estimates of daily nest survival probability were compared using a chi-square goodness-of-fit test. Vegetation height, density, cover, and arrival date were not normally distributed, and no transformation improved their distribution, so we tested for differences between the two plots using Mann-Whitney $U$-tests. We compared the mean abundance of predators between burned and harvested sites using an independent samples $t$-test (two-tailed). Values for daily nest survival probability and odds ratios are reported with 95\% upper and lower confidence limits because errors are asymmetrical about the mean. All other values are reported as means $\pm \mathrm{SE}$ and we used $\alpha=0.05$ as the level of statistical significance.

\section{RESULTS}

\section{VEGETATION DIFFERENCES BETWEEN HABITATS}

Burned and harvested plots were similar in the density of canopy-height $(>9 \mathrm{~m})$ tree trunks, density of canopy-height spruce and fir trunks, and in tree height diversity, suggesting that the two plots were similar in prefire forest structure and species composition (Table 1). The burned study plot had a greater snag density, a greater percentage of bare ground, and a lower density of live understory trees than the selectively harvested plot. Conversely, the harvested plot had a greater density of live trees and percentage of canopy cover. The density of suitable nest trees was greater in the harvested plot.

Male flycatchers selected territories on steeper slopes than were randomly available in both the burned and harvested study plots (Table 2). Male flycatchers settling in the burned study plot selected territories with ten times higher density of suitable nest trees compared to random plots, and territories in burned forest also contained significantly greater densities of snags than did randomly located plots.

We located 36 Olive-sided Flycatcher nests in burned and harvested forest. In the burned forest, most nest sites were located in highseverity burn patches (16 of $18,88 \%$ ); two nests were placed in mixed-severity patches. Overall, nests were found primarily in subalpine fir (24 
TABLE 2. Comparisons of vegetation structure characteristics at nest territories $(n=17)$ and random study plots $(n=18)$ in burned and harvested forests in northwestern Montana (mean $\pm \mathrm{SE})$. $P$-values are from Mann-Whitney $U$-tests comparing territories and random plots. Densities are reported as trees per hectare (see Table 1 for variable definitions). The density of suitable nest trees was greater in Olive-sided Flycatcher territories than in random plots in the burned study area.

\begin{tabular}{lcccccccc}
\hline \hline & \multicolumn{3}{c}{ Burned forest } & & \multicolumn{3}{c}{ Harvested forest } \\
\cline { 2 - 3 } \multicolumn{1}{c}{ Variable } & Territories & Random plots & $P$ & & Territories & Random plots & $P$ \\
\hline Ground slope (degrees) & $33.8 \pm 2.9$ & $15.9 \pm 5.1$ & & 0.01 & & $15.5 \pm 2.4$ & $7.2 \pm 0.9$ & $<0.001$ \\
Spruce and fir density & $34.3 \pm 9.1$ & $2.9 \pm 1.4$ & $<0.001$ & $53.2 \pm 15.0$ & $58.9 \pm 13.3$ & 0.78 \\
Suitable nest tree density & $30.5 \pm 8.3$ & $2.1 \pm 1.1$ & $<0.001$ & $32.3 \pm 11.0$ & $27.3 \pm 8.9$ & 0.64 \\
Snag density & $66.7 \pm 14.0$ & $132.1 \pm 32.0$ & 0.14 & & $15.8 \pm 3.3$ & $5.9 \pm 2.0$ & 0.02 \\
\hline
\end{tabular}

of 36, 66\%) and Engelmann spruce (10 of 36, $28 \%$ ). One nest each was built in western hemlock and western larch. In the burned study plot, most nests (17 of $18,94 \%)$ were placed in a dead subalpine fir in which the only remaining vegetation was a small cap of brown needles at the top of the tree. Nest placement in the harvested plot was more variable, but all nests in the harvested plot were placed in live trees. Nests placed in burned trees were located closer to the top of the nest tree, closer to the trunk, and were less concealed than nests in the harvested plot (Table 3). In general, Olive-sided Flycatcher nests were poorly concealed - concealment was less than $40 \%$ for all nests, regardless of treatment.

\section{HABITAT PREFERENCE}

Male flycatchers were first detected in both study plots on 25 May. However, settling male Olive-sided Flycatchers began defending territories on average 7.4 days earlier in the harvested plot (mean $=$ day $8.0 \pm 1.3)$ than in the burned plot (mean $=$ day $15.4 \pm 0.9 ; U=$ 27.5, $P<0.001$ ), indicating a preference for the harvested plot. Pairing success in the harvested plot $(76 \% \pm 7 \%)$ was higher than in the burned plot $(62 \% \pm 9 \%)$, but not significantly so $\left(t_{35}=1.2, P=0.25\right)$. Olive-sided Flycatcher territories were well spaced and were only rarely observed to abut one another, yet territory density was more than two times higher in the harvested study area ( 0.81 territories per $\mathrm{km}^{2}, n$ $=29)$ than in the burned study area $(0.38$ territories per $\mathrm{km}^{2}, n=28$ ).

\section{REPRODUCTIVE SUCCESS}

Estimated nest success in the burned plot (61\%) was twice that in the harvested plot $(30 \%)$. Daily nest survival rate in the selectively harvested plot was lower than that in the burned forest plot (harvested: 0.97, 95\% CI = 0.94-0.98; burned: $0.99,95 \% \mathrm{CI}=0.97-1.0 ; \chi^{2}{ }_{1}$ $=3.1, P=0.07$ ). This overall lower survival rate in the harvested plot was driven by the lower daily nest survival rate during the nestling period (harvested: $0.97,95 \% \mathrm{CI}=0.93-0.99$; burned: $0.99,95 \% \mathrm{CI}=0.97-1.0 ; \chi^{2}{ }_{1}=3.0, P$ $=0.08$ ). There was no difference in daily nest survival rate between treatments during the incubation period. We were unable to determine whether predation was responsible for all nest failures, but no failures were associated with extreme weather events. The outcome of two nests was unknown and these nests were not included in analysis.

The global model of nest survival fit the data well $\left(\chi_{8}^{2}=1.9, P=0.99\right)$. Three related models

TABLE 3. Comparisons of Olive-sided Flycatcher nest-site characteristics (mean \pm SE) in burned $(n=18)$ and selectively harvested $(n=17)$ study areas in northwestern Montana. $P$-values are for Mann-Whitney $U$ tests. Olive-sided Flycatcher nests were located closer to tree trunks and treetops and farther from concealing foliage in the burned study area.

\begin{tabular}{lccc}
\hline \hline \multicolumn{1}{c}{ Variable } & Burned forest & Harvested forest & $P$ \\
\hline Distance of nest from tree top $(\mathrm{m})$ & $1.2 \pm 0.2$ & $5.6 \pm 1.6$ & $<0.001$ \\
Distance from trunk to nest $(\mathrm{cm})$ & $7.0 \pm 3.4$ & $67.2 \pm 10.4$ & $<0.001$ \\
Distance from nest to outer foliage $(\mathrm{cm})$ & $17.6 \pm 2.9$ & $31.2 \pm 6.0$ & 0.02 \\
Distance from nest to foliage above $(\mathrm{cm})$ & $21.0 \pm 2.4$ & $42.0 \pm 6.1$ & 0.002 \\
\hline
\end{tabular}


TABLE 4. Candidate set of a priori models used to examine the effects of habitat type (burned vs. harvested), canopy cover, nesting stage (incubation vs. nestling), snag density, distance of nests from tree trunks, and ground slope on the daily survival of Olive-sided Flycatcher nests. Models were ranked using Akaike's information criterion corrected for small sample size $\left(\mathrm{AIC}_{c}\right)$; deviance is a measure of model fit; $K$ is the number of parameters estimated by the model, $\Delta \mathrm{AIC}_{c}$ is the difference in $\mathrm{AIC}_{c}$ between a given model and the model with the lowest $\mathrm{AIC}_{c}$ score, and Akaike weight reflects the relative support for each model. Note that two of the three best models contain the variables canopy cover and distance to trunk.

\begin{tabular}{|c|c|c|c|c|}
\hline Model & Deviance & $K$ & $\Delta \mathrm{AIC}_{c}{ }^{\mathrm{a}}$ & Akaike weight \\
\hline Canopy + Trunk distance & 117.01 & 3 & 0.00 & 0.31 \\
\hline Canopy & 120.44 & 2 & 1.41 & 0.15 \\
\hline Trunk distance & 120.46 & 2 & 1.43 & 0.15 \\
\hline Canopy + Habitat & 119.18 & 3 & 2.17 & 0.11 \\
\hline Trunk distance + Habitat & 120.26 & 3 & 3.25 & 0.06 \\
\hline Stage + Canopy & 120.17 & 3 & 3.43 & 0.06 \\
\hline Stage + Trunk distance & 119.80 & 3 & 3.44 & 0.06 \\
\hline Habitat & 123.50 & 2 & 4.46 & 0.03 \\
\hline Constant $^{\mathrm{b}}$ & 126.84 & 1 & 5.79 & 0.02 \\
\hline Slope & 125.12 & 2 & 6.10 & 0.01 \\
\hline Stage + Habitat & 126.50 & 3 & 6.37 & 0.01 \\
\hline Global $^{c}$ & 126.54 & 7 & 6.80 & 0.01 \\
\hline Snag & 126.54 & 2 & 7.52 & 0.01 \\
\hline Stage & 126.32 & 2 & 7.59 & 0.01 \\
\hline
\end{tabular}

a The lowest $\mathrm{AIC}_{c}$ score was 130.65 .

b The constant model contains no parameters.

c The global model contains all parameters.

received the greatest support in explaining variability in daily nest survival probability (Table 4). The best-fitting model contained variables describing forest canopy cover surrounding the nest and the distance of the nest from the tree trunk $(\mathrm{cm})$. The two next best models were single-parameter models containing these same variables. The summed weight of support for these best-fitting models is high relative to other models. Ultimately, selecting between the top three models is relatively unimportant as they produce nearly identical parameter estimates ( $\hat{\beta}$ from the three models are within 0.001 of one another). However, for the purpose of estimating daily nest survival, we accepted $S_{\text {canopy }}+$ trunk distance as the best-fitting model because it was more parsimonious despite the penalty for an increased number of parameters in the model. The logistic regression equation for the best model was:

$$
\begin{aligned}
\operatorname{Logit}\left(\hat{S}_{i}\right) & =4.40-0.05(\text { canopy }) \\
& -0.02(\text { trunk distance }) .
\end{aligned}
$$

By incorporating values for the selected covariates to solve this equation, we found decreased daily survival for nests surrounded by denser canopy and for nests placed farther from the trunk of the nest tree.

Although parameter estimates and associated standard errors reveal the relative strength and direction of each effect, converting these values to odds ratios and $95 \%$ confidence intervals allows additional interpretation of effect size. Canopy cover had the strongest effect on nest success, with a $1 \%$ increase in canopy cover producing a $0.5 \%$ decrease in the odds of a nest surviving a given day (odds ratio $=0.95,95 \%$ $\mathrm{CI}=0.94-0.98)$. This means that a $50 \%$ increase in canopy cover produces a $25 \%$ decrease in the odds of a nest surviving a given day. Each centimeter a nest was located farther from the trunk increased the probability of nest failure by $2 \%$ (odds ratio $=0.98,95 \% \mathrm{CI}=$ $0.96-0.99$ ). This is equivalent to a $20 \%$ decrease in the odds of daily nest survival for each extra $10 \mathrm{~cm}$ distance from the nest tree trunk.

\section{NEST PREDATOR ABUNDANCE AND FOOD AVAILABILITY}

Known nest predator species were estimated to be more than twice as abundant in the harvested plot than in the burned forest plot (red squirrel: $t_{132}=3.5, P=0.001$; Common Raven: $t_{88}=2.3, P=0.02$; Gray Jay: $t_{87}=2.4$, 


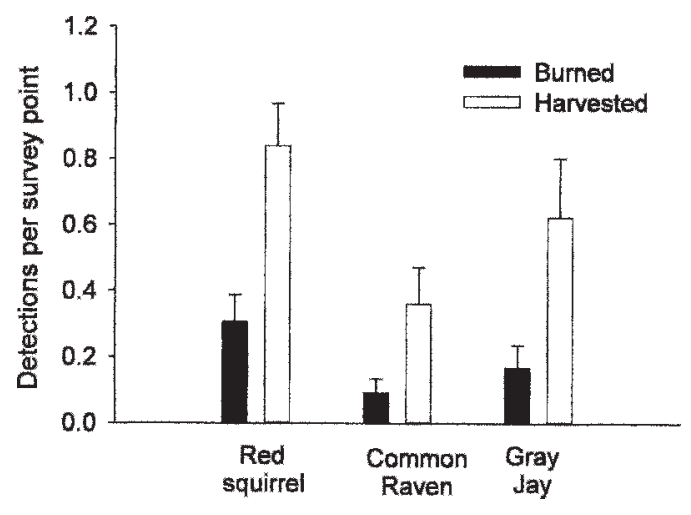

FIGURE 1. Mean ( \pm SE) number of red squirrel ( $n$ $=132)$, Common Raven $(n=88)$, and Gray Jay $(n=$ 87) detections per survey point in burned and selectively harvested study areas in northwestern Montana in 2002. These potential Olive-sided Flycatcher nest predator species were detected less frequently in burned than in selectively harvested, unburned forest areas.

$P=0.02$; Fig. 1). Mean chick provisioning rates (feedings per chick per hour) were higher for adult flycatchers in harvested than in burned forest habitat (harvested: $5.4 \pm 0.4$; burned: $4.0 \pm 0.4 ; t_{32}=2.5, P=0.02$ ). Allocation rates did not differ between morning and afternoon sampling sessions.

\section{DISCUSSION}

Results from this study are consistent with the hypothesis that, relative to burned forests, selectively harvested forests serve as ecological traps for Olive-sided Flycatchers. Birds arriving on the breeding grounds appear to have preferentially selected the poorer quality habitat. This may represent a 'severe' trap (Robertson and Hutto 2006), which results when habitat selection cues make a relatively poorquality habitat more attractive than a higher quality habitat.

There are several reasons why an Olive-sided Flycatcher might prefer the harvested forest to the burned forest. One possibility is a greater availability of suitable nest trees in a harvested forest. The significantly greater density of spruce and fir trees in burned territories compared to random postfire locations suggests that nest tree availability is an important habitat selection cue for this species, and the comparatively higher availability of suitable nest trees in the selectively harvested landscape might provide a mechanism by which the attractiveness of this habitat could exceed that of the burned forest. The strong preference for spruce and fir trees as nesting substrates in this study ( $94 \%$ of nests) parallels patterns of use observed in other studies (reviewed by Altman and Sallabanks 2000) and is attributable to a branching and leafing structure suitable for the woven nest types used by Olive-sided Flycatchers (Altman and Sallabanks 2000). It is unclear if the observed differences in nest site characteristics between treatments are adaptive responses to differences in predation pressure or microclimate between habitat types, or a consequence of unmeasured factors.

Another possible reason that flycatchers might prefer the harvested forest is a greater early season abundance of food relative to the burned forest. Chicks received food at a greater rate in harvested patches in both this study and in a study conducted in California (Brandy 2001). Moreover, food availability and peak foraging rates for Olive-sided Flycatchers are tightly correlated and significantly higher in harvested than in burned forest, and that pattern holds true across breeding seasons and years (Meehan and George 2003). Aerial insectivores grow more slowly than similarsized species of perching insectivores in both temperate and tropical regions (Ricklefs 1976) because young store lipids as "insurance fat" against temporary food shortages that can cause starvation (Lack and Lack 1951). For this reason, habitat characteristics that increase foraging efficiency are likely to be especially important. That territories with steep slopes were preferred may also be attributable to the fact that perches on steep slopes provide a greater open field of clear sky, which could facilitate prey capture (Fitzpatrick 1981).

The difference in daily nest survival rate between treatments was only marginally significant in a statistical sense, but may be biologically significant nonetheless. Olive-sided Flycatchers have the longest nesting period of any North American passerine ( $\sim 38$ days [incubation + nestling periods]; Altman and Sallabanks 2000). Based on this long nesting period, total nest success in the burned plot $(61 \%)$ was twice that of the harvested plot (30\%). These results closely match published estimates of nest success in these habitat types from a slightly broader range of harvested age 
classes and postfire years (Altman and Sallabanks 2000).

While we have no data on the population consequences of this ecological trap, such a discrepancy in overall nest success is likely to exert pressure on habitat selection behavior. Most nest failures in the harvested area took place during the nestling phase when food provisioning rates were relatively high, suggesting the activity of nest predators as the causal agent. The likelihood of nest predation by visually oriented predators increases during the nestling phase because the high level of parental activity around the nest can cue predators to its location (Martin et al. 2000). Furthermore, lower nest predator abundance (avian and mammalian) in postfire landscapes relative to green and harvested landscapes is emerging as a general ecological pattern (Stuart-Smith and Hayes 2003, Smucker et al. 2005). Consequently, early successional postfire habitat may represent relatively enemy-free space for many songbirds that have evolved to breed in recently burned landscapes.

Because severe ecological traps result from the inappropriate stimulation of an innate or learned settling response of an organism by one or more environmental cues, it may be relatively easy to decrease the appeal of these sites by managing the cues that attract a species. Results from this study suggest at least two potential habitat selection cues that could be managed to reduce the attractiveness of selectively harvested habitat to Olive-sided Flycatchers: (1) snag density, and (2) spruce and fir density. Snags are thought to be important foraging resources for flycatchers through the provision of unobstructed views and flight paths for pursuing insects (Altman and Sallabanks 2000), and flycatchers settling in the harvested landscape in this study appeared to prefer patches with a greater snag density. If snag abundance and suitable nest tree density act as habitat selection cues for this species, removal or reduction of these elements should reduce the attractiveness of harvested forest types to Olive-sided Flycatchers. However, even if the removal of snags and certain tree species from harvest units were economically and logistically feasible, such activity would conflict with habitat management guidelines for other species, notably snag-dependent bird species (e.g., woodpeckers and secondary cavity-nesters). Moreover, studies examining settling responses of Olive-sided Flycatchers to experimental manipulations of potential habitat selection cues are needed before management implications are fully understood.

It is important that we address several issues that might emerge from the results of this study. First, we acknowledge that a behavioral strategy that reduces survival or reproduction in the short term is not necessarily maladaptive if it enhances longer-term reproductive success. For example, characteristics of successful nest sites can vary over time and space (van Riper 1984), and nest-site selection may reflect a long-term optimum that is, at times, neutral or maladaptive in the short term (Clark and Shutler 1999). Furthermore, we wish to emphasize that an ecological trap is a behavioral, not a population, phenomenon (Robertson and Hutto 2006). Traps are defined by the mismatch between an individual's perception of habitat quality (proximal cues) and the actual habitat quality itself (ultimate factors), rather than by habitatspecific population growth rates. Thus, while the presence of an ecological trap may indeed reduce the likelihood of population persistence, absolute or relative population growth rates are not diagnostic characteristics of ecological traps (Robertson and Hutto 2006).

Another issue that emerges from our approach to assess habitat preference is whether relative abundance or arrival time is a reasonable surrogate for preference. It is possible, for example, that average arrival time is influenced by site fidelity, and that because the harvested sites were occupied by birds the previous year and burned sites probably were not, this may have biased the arrival time estimate to be earlier in the harvested site. However, although males in this study began defending territories within the harvested habitat first, males began arriving at (and possibly assessing habitat quality in) both study sites at the same time. Thus, coupled with the difference in relative abundance between sites, the difference in average arrival time probably reflects a true preference by the birds, as discussed more fully elsewhere (Robertson and Hutto 2006).

With no treatment-level replication, we acknowledge that it is difficult to attribute differences in nest success between plots to the more general effects of either timber harvesting or fire. It is also relevant to consider which naturally occurring vegetation should serve as 
a "control" to test for the existence of an ecological trap. Ultimately, though, the answer does not matter. Just as adaptive traits can be identified only through comparisons among selective regimes (Reeve and Sherman 1993), maladaptive habitat selection behavior can be demonstrated only through comparisons of the fitness consequences of a particular behavior in different habitat types. Thus, independent of whatever habitat might be "optimal" for this species, it appears that the selectively harvested site in this study acted as an ecological trap relative to the early postfire site.

Because our study suffers from a lack of treatment-level replication, it will only be after a number of similar studies are published that we will be able to assess the generality of our results. Nonetheless, these results are important because they underscore the potential danger of altering or even "restoring" vegetation conditions if resulting conditions resemble a naturally occurring vegetation type only superficially. Indeed, recent evidence suggests that a similar mechanism may be operating to generate ecological traps in other habitat types. For example, (Shochat et al. 2005) found that habitat preferences in grassland birds were affected by arthropod availability while nesting success was determined by nest predator abundance. With increasing interest in mimicking nature through management (Arno and Fiedler 2005), we must be careful to consider whether the ultimately important features of a habitat (e.g., food, shelter, and predators) are appropriately coupled with the environmental cues that are created through management actions. The creation of an ecological trap may be an unintended consequence of attempting to more closely mimic the effects of natural disturbance, which reveals the complexity of managing artificial landscapes for native biodiversity. Our results also suggest that animal behavior is a critical component in studies of the effects of management (Caro 1998). The possibility that we might be creating ecological traps through land management activities should compel conservation biologists to examine more closely not just habitat quality, but also habitat attractiveness.

\section{ACKNOWLEDGMENTS}

We thank AmeriCorps and the Mazamas mountaineering organization for funding, and D. Brown for field assistance. We would also like to thank Plum Creek Timber Company and the Flathead National Forest for permission to conduct this study on their lands. Thanks also to K. Short and R. Fletcher for their input and logistical support, D. Dobkin, and T. Sachtleben for editorial comments, two anonymous reviewers for constructive criticism, and F. Villaseñor for the Spanish translation of the abstract.

\section{LITERATURE CITED}

Aebischer, A., N. Perrin, M. Krieg, J. Studer, AND D. R. MEYER. 1996. The role of territory choice, mate choice and arrival date on breeding success in the Savi's Warbler Locustella luscibioides. Journal of Avian Biology 27:143-152.

AKAIKE, H. 1973. Information theory and an extension of the maximum likelihood principle, p. 267-281. In B. Petran and F. Csaki [EDS.], International symposium on information theory. Akademiai Kiado, Budapest, Hungary.

Altman, B., And R. Sallabanks. 2000. Olive-sided Flycatcher (Contopus cooperi). In A. Poole and F. Gill [EDS.], The birds of North America, No. 502. The Birds of North America, Inc., Philadelphia, PA.

Anderson, D. R., K. P. Burnham, And W. L. THOMPSON. 2000. Null hypothesis testing: problems, prevalence, and an alternative. Journal of Wildlife Management 64:912-923.

Arno, S. F., AND C. E. FIEDLER. 2005. Mimicking nature's fire: restoring fire-prone forests in the West. Island Press, Washington, DC.

BensCh, S., AND D. Hasselquist. 1991. Territory infidelity in the polygynous Great Reed Warbler Acrocephalus arundinaceus: the effect of variation in territory attractiveness. Journal of Animal Ecology 60:857-871.

BLANCHER, P. J., AND R. J. Robertson. 1987. Effect of food supply on the breeding biology of Western Kingbirds. Ecology 68:723-732.

BRANDY, P. M. 2001. A hierarchical analysis of Olive-sided Flycatcher habitat use in a managed landscape. M.Sc. thesis, Humboldt State University, Arcata, CA.

Burnham, K. P., AND D. R. Anderson. 1998. Model selection and inference: a practical information-theoretic approach. Springer-Verlag, New York.

Burnham, K. P., AND D. R. Anderson. 2001. Kullback-Leibler information as a basis for strong inference in ecological studies. Wildlife Research 28:111-119.

CARO, T. 1998. The significance of behavioral ecology for conservation biology, p. 3-26. In T. Caro [ED.], Behavioral ecology and conservation biology. Oxford University Press, New York.

Clark, R. G., AND D. Shutler. 1999. Avian habitat selection: pattern from process in nestsite use by ducks? Ecology 80:272-287.

Currie, D., D. B. Thompson, And T. Burke. 2000. Patterns of territory settlement and consequences for breeding success in the Wheatear Oenanthe oenanthe. Ibis 142:389-398. 
Delibes, M., P. GaOna, And P. Ferreras. 2001 Effects of an attractive sink leading into maladaptive habitat selection. American Naturalist 158:277-285.

Delong, S. C., And D. TAnner. 1996. Managing the pattern of forest harvest: lessons from wildfire. Biodiversity and Conservation 5:11911205.

Donovan, T. M., And F. R. Thompson III. 2001. Modeling the ecological trap hypothesis: a habitat and demographic analysis for migrant songbirds. Ecological Applications 11:871-882.

DWERNYCHUK, L. W., AND D. A. BOAG. 1972. Ducks nesting in association with gulls - an ecological trap? Canadian Journal of Zoology 50:559-563.

FITZPATRICK, J. W. 1981. Search strategies of tyrant flycatchers. Animal Behavior 29:810-821.

FRANSSON, T., AND S. JAKOBSSON. 1998. Fat storage in male Willow Warblers in spring: do residents arrive lean or fat? Auk 115:759-763.

Frost, C. C. 1998. Presettlement fire frequency regimes of the United States: a first approximation, p. 70-81. In T. Pruden and L. Brennan [EDS.], Fire in ecosystem management: shifting the paradigm from suppression to prescription. Tall Timbers fire ecology conference proceedings No. 20. Tall Timbers Research Station, Tallahasee, FL.

HABECK, J. R., AND R. W. Mutch. 1973. Firedependent forests in the northern Rocky Mountains. Quaternary Research 3:408-424.

Hejl, S. J., R. L. Hutto, C. R. Preston, And D. M. FINCH. 1995. Effects of silvicultural treatments in the Rocky Mountains, p. 220-244. In T. E. Martin and D. M. Finch [EDS.], Ecology and management of Neotropical migratory birds: a synthesis and review of critical issues. Oxford University Press, New York.

Holling, C. S. 1965. The functional response of predators to prey density and its role in mimicry and population regulation. Memoirs of the Entomological Society of Canada 45:1-60.

Holling, C. S. 1966. The functional response of invertebrate predators to prey density. Memoirs of the Entomological Society of Canada 48:1-86.

Hosmer, D. W., JR, AND S. LEMESHOW. 1989. Applied logistic regression. John Wiley and Sons, New York.

HutTo, R. L. 1985. Habitat selection by nonbreeding migratory land birds, p. 455-476. In M. Cody [ED.], Habitat selection in birds. Academic Press, London.

Hutto, R. L. 1990. Measuring the availability of food resources. Studies in Avian Biology $13: 20-28$

Hutto, R. L. 1995. Composition of bird communities following stand-replacement fires in northern Rocky Mountain (U.S.A.) conifer forests. Conservation Biology 9:1041-1058.

Hutto, R. L., AND J. S. Young. 1999. Habitat relationships of landbirds in the Northern Region. USDA Forest Service General Technical Report RMRS-GTR-32.
Kokko, H. 1999. Competition for early arrival in migratory birds. Journal of Animal Ecology 68:940-950.

KokKo, H., AND W. J. Sutherland. 2001. Ecological traps in changing environments: ecological and evolutionary consequences of a behaviourally mediated Allee effect. Evolutionary Ecology Research 3:537-551.

LACK, D., AND E. LACK. 1951. The breeding biology of the swift Apus apus. Ibis 93:501-546.

LEVINS, R. 1968. Evolution in changing environments. Princeton University Press, Princeton, NJ.

Martin, T. E., J. Scott, AND C. Menges. 2000. Nest predation increases with parental activity: separating nest site and parental activity effects. Proceedings of the Royal Society of London Series B 267:2287-2293.

Meehan, T. D., And T. L. George. 2003. Shortterm effects of moderate- to high-severity wildfire on a disturbance-dependent flycatcher in northwest California. Auk 120:1102-1113.

Misenhelter, M. D., AND J. Rotenberry. 2000. Choices and consequences of habitat occupancy and nest site selection in Sage Sparrows. Ecology 81:2892-2901.

Pereyra, M. E., AND M. L. Morton. 2001. Nestling growth and thermoregulatory development in subalpine Dusky Flycatchers. Auk 118:116-136.

Ralph, C. J., G. R. Geupel, P. Pyle, T. E. Martin, AND D. F. Desante. 1993. Handbook of field methods for monitoring landbirds. USDA Forest Service General Technical Report PSWGTR-144.

Reeve, H. K., And P. W. Sherman. 1993. Adaptation and the goals of evolutionary research. Quarterly Review of Biology 68:1-32.

RICKLEFS, R. E. 1976. Growth rate of birds in the humid New World tropics. Ibis 118:176-207.

Robertson, B. A., AND R. L. Hutto. 2006. A framework for understanding ecological traps and an evaluation of existing evidence. Ecology 87:1075-1085.

SAS InstituTE. 1999. SAS/STAT user's guide. Version 8. SAS Institute, Inc., Cary, NC.

Schlaepfer, M. A., M. C. Runge, And P. W. SHERMAN. 2002. Ecological and evolutionary traps. Trends in Ecology \& Evolution 17:474 480.

Shaffer, T. L. 2004. A unified approach to analyzing nest success. Auk 121:526-540.

SHANNON, C. E., AND W. WeAver. 1963. The mathematical theory of communication. University of Illinois Press, Urbana, IL.

Shochat, E., M. A. Patten, D. W. Morris, D. L. Reinking, D. H. Wolfe, and S. K. Sherrod. 2005. Ecological traps in isodars: effects of tallgrass prairie management on bird nest success. Oikos 111:159-169.

Short, K. C., And J. F. Negrón. 2003. Arthropod responses: a functional approach, p. 286-305. In P. Friederici [ED.], Ecological restoration of southwestern ponderosa pine forests. Island Press, Washington, DC.

SkutCH, A. F. 1949. Do tropical birds rear as many young as they can nourish? Ibis 91:430-455. 
Smucker, K. M., R. L. Hutto, and B. M. Steele. 2005. Changes in bird abundance after wildfire: importance of fire severity and time since fire. Ecological Applications 15:1535-1549.

Spies, T. A., W. J. Ripple, AND G. A. Bradshaw. 1994. Dynamics and pattern of a managed coniferous forest landscape in Oregon. Ecological Applications 4:555-568.

Stuart-Smith, K. A., And J. P. Hayes. 2003. Influence of residual tree density on predation of artificial and natural songbird nests. Forest Ecology and Management 183:159-176.

TinBERGEN, N. 1951. The study of instinct. Oxford University Press, Oxford, UK.
U.S. Department OF THE INTERIOR. 2002. Fire monitoring handbook. National Interagency Fire Center, Boise, ID.

VAN RIPER, C., III. 1984. The influence of nectar resources on nesting success and movement patterns of the Common Amakihi. Auk 101: 38-46.

WAlsBerG, G. E. 1978. Brood size and the use of time and energy by the Phainopepla. Ecology 59: $147-153$

Weldon, A. J., And N. M. Haddad. 2005. The effects of patch shape on Indigo Buntings: evidence for an ecological trap. Ecology 86: 1422-1431. 